\title{
OPEN Publisher Correction: Optimizing the dynamics of protein expression
}

\section{Jan-Hendrik Trösemeier, Sophia Rudorf $₫$, Holger Loessner, Benjamin Hofner,

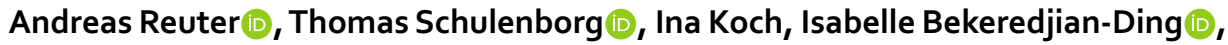 Reinhard Lipowsky \& Christel Kamp (i)}

Correction to: Scientific Reports https://doi.org/10.1038/s41598-019-43857-5, published online 17 May 2019

In the original version of this Article, Jan-Hendrik Trösemeier was incorrectly affiliated with 'Division of Allergology, Paul Ehrlich Institut, Langen, Germany' The correct affiliations are listed below.

Division of Microbiology, Paul Ehrlich Institut, Langen, Germany

Max Planck Institute of Colloids and Interfaces, Potsdam-Golm Science Park, Potsdam, Germany

Goethe University Frankfurt, Institute of Computer Science, Molecular Bioinformatics, Frankfurt am Main, Germany

This error has now been corrected in the HTML and PDF versions of this Article.

(c) (i) Open Access This article is licensed under a Creative Commons Attribution 4.0 International License, which permits use, sharing, adaptation, distribution and reproduction in any medium or format, as long as you give appropriate credit to the original author(s) and the source, provide a link to the Creative Commons license, and indicate if changes were made. The images or other third party material in this article are included in the article's Creative Commons license, unless indicated otherwise in a credit line to the material. If material is not included in the article's Creative Commons license and your intended use is not permitted by statutory regulation or exceeds the permitted use, you will need to obtain permission directly from the copyright holder. To view a copy of this license, visit http://creativecommons.org/licenses/by/4.0/.

(C) The Author(s) 2020 